\title{
Effect of Solution Heat Treatment and Artificial Aging on Compression Behaviour of A356 Alloy
}

\author{
Dhanashekar MANICKAM*, Senthil Kumar VELUKKUDI SANTHANAM
} Department of Mechanical Engineering, College of Engineering Guindy, Anna University, Chennai - 600025, Tamil
Nadu, India

cross $^{\text {ref }}$ http://dx.doi.org/10.5755/j01.ms.25.3.20442

\section{Received 27 March 2018; accepted 24 July 2018}

\begin{abstract}
Aluminium alloys are subjected to heat treatment to increase the strength and corrosion properties. This paper aims to study the effect of heat treatment on the compression behaviour of A356 alloy under quasi static condition and barreling effect. The various heat treatments are: (i) solution heat treatment of $1 \mathrm{~h}$ at $540{ }^{\circ} \mathrm{C}+$ natural aging $0 \mathrm{~h}+\operatorname{artificial}$ aging at $180{ }^{\circ} \mathrm{C}$ up to $5.5 \mathrm{~h}$, (ii) solution heat treatment of $3 \mathrm{~h}$ at $540{ }^{\circ} \mathrm{C}+$ natural aging for $20 \mathrm{~h}+$ artificial aging at $180{ }^{\circ} \mathrm{C}$ up to $5.5 \mathrm{~h}$, and (iii) solution heat treatment of $6 \mathrm{~h}$ at $540{ }^{\circ} \mathrm{C}+$ natural aging for $20 \mathrm{~h}+$ artificial aging at $180{ }^{\circ} \mathrm{C}$ up to $5.5 \mathrm{~h}$. Specially to understand the influence of artificial aging at every $0.5 \mathrm{~h}$ up to $5.5 \mathrm{~h}$, the specimens were heat treated. From the results, solutionizing for $1 \mathrm{hr}$ have a better compression strength irrespective of the artificial aging. Natural aging had decreased the ductility but increased the strength property. Artificial aging had a significant effect on the compressive strength and peak strength were obtained at $4 \mathrm{~h}$ irrespective of solutionizing heat treatment. Compressive strength increased by $33 \%$ for $1 \mathrm{~h}$ of solutionizing and $4 \mathrm{~h}$ of artificial aged specimen when compared to non-heat treated alloy. Two mathematical relations discussed in literature were used for calculating the radius of the barreled surface followed by validation.
\end{abstract}

Keywords: A356 alloy, compressive strength, heat treatment, barrel radius, artificial aging.

\section{INTRODUCTION}

Heat treatment can be defined as a process, in which a metal is heated to a certain temperature and then cooled in a particular manner to alter its internal structure for obtaining the desired degree of physical and mechanical properties such as hardness, strength, corrosion resistance etc. A356 alloy is widely used in automobile and aerospace components due to its excellent cast properties and high corrosion resistance. These components are subjected to various heat treatments, by varying the solutionizing and aging process sequence, in order to attain better properties [1].

Industries follow the ASTM B917 and ASTM B91 standards for precipitation hardening or called as T6 heat treatment, which involves a solution heat treatment, soaking and aging process. The T6 heat treatment is solution heat treatment at a temperature of $540{ }^{\circ} \mathrm{C}$, with residence duration that may vary between $6 \mathrm{hr}$ and $12 \mathrm{~h}$, and then artificially aging at $155^{\circ} \mathrm{C}$, between $3 \mathrm{~h}$ and $5 \mathrm{~h}$ [2]. The solution treatment stage holds three important sequences. First, the as-cast eutectic Si phase splits (which occurs as interconnected flakes in unmodified alloys, and fibrous coral-like structures in modified alloys) into small spherical discrete particles. Secondly, it causes the dissolution of the $\mathrm{Mg}$-containing micro-constituents (i.e. $\mathrm{Mg}_{2} \mathrm{Si}$ and $\pi-\mathrm{A} 19 \mathrm{Mg} 3 \mathrm{FeSi} 5$ phase2) thus enriching the $\mathrm{Mg}$ and $\mathrm{Si}$ content of the aluminium solid solution. Thirdly, it homogenizes the distribution of $\mathrm{Mg}$ and $\mathrm{Si}$ across the dendrite arms of the primary aluminium grains [3]. Rosse and Actis Grande, have suggested that solutionizing the

\footnotetext{
${ }^{*}$ Corresponding author. Tel.: +91-9677167683.

E-mail address: dhanashekar.phd@gmail.com (M. Dhanashekar)
}

metal for $1 \mathrm{~h}$ rather than $6 \mathrm{~h}$ would yield significantly better tensile strength and the solution heat treatment time of $1 \mathrm{~h}$ at $540{ }^{\circ} \mathrm{C}$ further subjected to $180{ }^{\circ} \mathrm{C}$ for $4 \mathrm{~h}$ by artificial ageing can yield better mechanical properties [4]. Dewhrist [5], indicates that the optimum time for natural aging is less than $8 \mathrm{~h}$ for cast aluminum alloy and that for artificial aging is $4 \mathrm{~h}$. Shivkumar et al [6] and Zhang et al [7], have found solution heat treatment temperature of $540{ }^{\circ} \mathrm{C}$ was sufficient and followed by artificial ageing time $3-5 \mathrm{~h}$ at $155^{\circ} \mathrm{C}$, can yield better hardness and strength. Solution treatment is followed by the subsequent artificial ageing treatment, during which fine scale $\mathrm{Mg}-\mathrm{Si}$ precipitates producing desirable mechanical properties for specific applications [3]. The ductility of artificially aged aluminium alloys is known to depend on several aspects: primary particles (amount, size, shape and distribution); intergranular precipitation and precipitate free zones in the vicinity of the grain boundaries; the plastic behaviour of the grain; and crystallographic and morphological texture produced by the forming process [8].

Based on the literature, the total time of the T6 heat treatment cycle should be considered in having a significant impact on productivity and manufacturing cost of a cast component and for this reason, there was a strong interest in establishing the feasibility of reducing the solution heat treatment time. Researchers have studied the effect of artificial aging on tensile strength, corrosion resistance and grain refinement of various aluminium alloys. During the compression of solid cylinder (or other geometrical shape) specimen in between axisymetrically placed flat platens, the metal directly under the contact of the platen surfaces is restricted to flow outside, while the metal away from the platen surfaces is free to flow in an 
outward direction (Fig. 2 c) [9]. This leads to the bulging or barreling. Kobayashi concluded an increase in friction increases barreling [10]. Many researchers have explained clearly the reason behind the occurrence of barreling or pancaking in forging.

However, the effect of artificial aging on the compression strength and the barrel radius have not been investigated. Therefore, this paper deals with the study on compressive behaviour of A356 alloy subjected to a modified heat treatment i.e. solution treatment time of $1 \mathrm{~h}$, $3 \mathrm{~h}$ and $6 \mathrm{~h} \mathrm{(at} 540{ }^{\circ} \mathrm{C}$ ), natural aging at $0 \mathrm{~h}$ and $20 \mathrm{~h}$, artificial aging time range in $0.5 \mathrm{~h}, 1 \mathrm{~h}, 1.5 \mathrm{~h}, \ldots 5.5 \mathrm{~h}$ (at $180{ }^{\circ} \mathrm{C}$ ). The effect of solution treatment and aging on the compression behaviour and barreling effect are discussed.

\section{EXPERIMENTAL DETAILS}

A356 alloy has been considered for this study and its chemical composition is given in Table 1 was heat treated at three different series such as : (i) Series A "Solutionizing $\left(540{ }^{\circ} \mathrm{C}-1 \mathrm{~h}\right)$, no natural aging, artificial aging $\left(180^{\circ} \mathrm{C}-0.5,1,1.5, \ldots 5.5 \mathrm{~h}\right)$ ", Series B "Solutionizing $\left(540^{\circ} \mathrm{C}-3 \mathrm{~h}\right)$, natural aging $(20 \mathrm{~h})$, artificial aging $\left(180^{\circ} \mathrm{C}-0.5,1,1.5, \ldots 5.5 \mathrm{~h}\right)$ ", and Series $\mathrm{C}-$ "Solutionizing $\left(540^{\circ} \mathrm{C}-6 \mathrm{~h}\right)$, natural aging $(20 \mathrm{~h})$, artificial aging $\left(180^{\circ} \mathrm{C}-0.5,1,1.5, \ldots 5.5 \mathrm{~h}\right)$ " in electric muffle furnace with the accuracy of furnace temperature maintenance was $\pm 5^{\circ} \mathrm{C}[11]$.

Table 1. Chemical composition of A356 alloy

\begin{tabular}{|c|c|c|c|c|c|c|}
\hline Elements & $\mathrm{Cu}$ & $\mathrm{Si}$ & $\mathrm{Mg}$ & $\mathrm{Mn}$ & $\mathrm{Fe}$ & $\mathrm{Ti}$ \\
\hline wt.\% & 0.02 & 6.99 & 0.48 & 0.02 & 0.22 & 0.18 \\
\hline Elements & $\mathrm{Ni}$ & $\mathrm{Zn}$ & $\mathrm{Pb}$ & $\mathrm{Sn}$ & \multicolumn{2}{|c|}{$\mathrm{Al}$} \\
\hline wt.\% & 0.01 & 0.04 & $<0.001$ & 0.001 & \multicolumn{2}{|c|}{ Balance } \\
\hline
\end{tabular}

The microstructure of the base alloy is shown in Fig. 1. The alloy subjected to different heat treatment are identified with a specific specimen ID (ex: A1, A2, A3, etc.) as given in Table 2. The compression test specimens were prepared according to the ASTM E9 standard with dimensions of $16 \mathrm{~mm}$ diameter and $26 \mathrm{~mm}$ length, with the aspect ratio of $0.62(l / d$ ratio $=1.625)$. The flat surfaces were mirror polished and compressed under friction. All the compression test was conducted at a crosshead speed $0.5 \mathrm{~mm} / \mathrm{s}$, without lubrication between specimen and die [12].
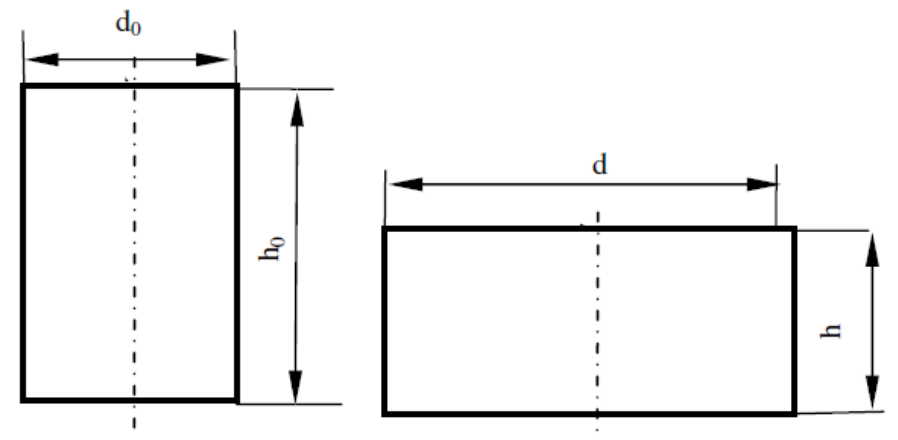

a

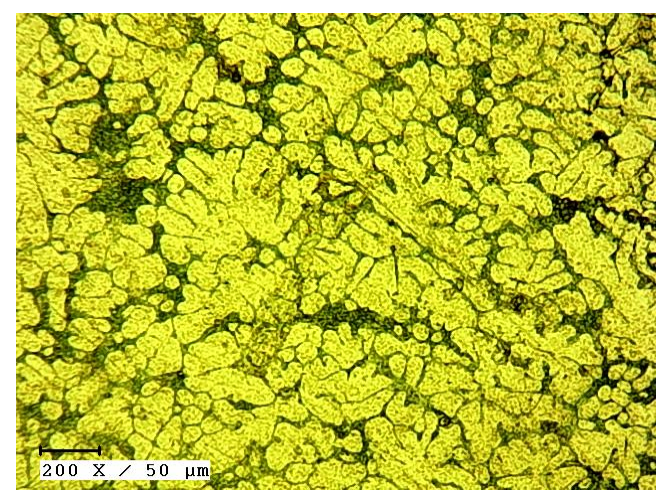

Fig. 1. Microstructure of A356 alloy

The barreling profile follows a circular arc [13] with radius depending on true axial compressive stresses. The radius of the barreled surface [14] was obtained during the upsetting at flat faced dies as shown in Fig. 2 using the Pythagorean Theorem given in Eq. 1 (considering the shape as a circular arc). Narayanasamy and Pandey [15] obtained the radius of curvature for the upsetting of annealed aluminum cylindrical part as given in Eq. 2. Abhijit Mukhopadhay [12] has calculated the upsetting ratio while upsetting pure aluminium cylinder under dry condition using Eq. 3.

$R=\left(h^{2}+\left(d_{2}-d_{l}\right)^{2} /\left(4\left(d_{2}-d_{l}\right)\right) ;\right.$

$R^{1 / 2}=\left[h_{0} / 2\left(d_{2}-d_{l}\right)^{1 / 2}\right] \times\left[3 d_{0}^{2} /\left(2 d_{2}^{2}+d_{l}^{2}\right)\right] ;$

$e=\left[\left(h_{0}-h\right) / h_{0}\right] \times 100$.

The notations used are provided in Fig. 2. The elemental composition was done using Scanning Electron Microscopy (SEM) with Energy Dispersive X-ray Spectroscopy (EDS) analysis with an acceleration voltage of $10 \mathrm{kV}$, secondary electron detector (Hitachi S-3400N, Japan).

\section{RESULTS AND DISCUSSION}

\subsection{Effect of heat treatment on compressive strength}

The compression test for heat treated A356 alloy was carried out using a Universal Testing Machine (Instron-50 KN) where the compression plates compresses the workpiece, the load increases gradually and the compression length is computed. The compression test results are given in Table 2 .

Fig. 2. Upsetting at flat faced dies: $a$-initial; b-ideal; $c$-real positions [13] 
Table 2. Compression strength, upset ratio, barrel radius of deformed specimens at various heat treated conditions

\begin{tabular}{|c|c|c|c|c|c|c|c|c|c|c|}
\hline No & $\begin{array}{l}\text { Specimen } \\
\text { ID }\end{array}$ & $\begin{array}{c}\text { Solution heat } \\
\text { treatment }\end{array}$ & $\begin{array}{c}\text { Natural } \\
\text { aging }\end{array}$ & $\begin{array}{l}\text { Artificial } \\
\text { aging }\end{array}$ & $\begin{array}{l}\text { Compressive } \\
\text { strength, MPa }\end{array}$ & $\begin{array}{c}\text { YL0.2\% PL, } \\
\text { KN }\end{array}$ & $\mathrm{e}$ & $\mathrm{R}_{\mathrm{a}}, \mathrm{mm}$ & $\mathrm{R}_{\mathrm{b}}, \mathrm{mm}$ & $\begin{array}{c}\text { Deviation, } \\
\mathrm{R}_{\mathrm{a}}-\mathrm{R}_{\mathrm{b}}\end{array}$ \\
\hline 1 & $\mathrm{~A} 1$ & \multirow{11}{*}{$540^{\circ} \mathrm{C}-1 \mathrm{hr}$} & \multirow{11}{*}{$0 \mathrm{~h}$} & $180^{\circ} \mathrm{C}-0.5 \mathrm{~h}$ & \begin{tabular}{|l|}
94 \\
\end{tabular} & 18.67 & 45.92 & 17.60 & 16.54 & 1.06 \\
\hline 2 & A2 & & & $180^{\circ} \mathrm{C}-1 \mathrm{~h}$ & 122 & 24.14 & 25.73 & 41.24 & 37.89 & 3.35 \\
\hline 3 & A3 & & & $180^{\circ} \mathrm{C}-1.5 \mathrm{~h}$ & 197 & 39.02 & 19.08 & 67.57 & 64.31 & 3.26 \\
\hline 4 & A4 & & & $180^{\circ} \mathrm{C}-2 \mathrm{~h}$ & 213 & 42.39 & 24.50 & 43.83 & 42.08 & 1.75 \\
\hline 5 & A5 & & & $180^{\circ} \mathrm{C}-2.5 \mathrm{~h}$ & 219 & 43.51 & 19.92 & 49.94 & 43.73 & 6.21 \\
\hline 6 & A6 & & & $180^{\circ} \mathrm{C}-3 \mathrm{~h}$ & 216 & 42.95 & 23.27 & 46.27 & 44.13 & 2.14 \\
\hline 7 & A7 & & & $180^{\circ} \mathrm{C}-3.5 \mathrm{~h}$ & 226 & 44.91 & 19.23 & 55.35 & 51.25 & 4.1 \\
\hline 8 & A8 & & & $180^{\circ} \mathrm{C}-4 \mathrm{~h}$ & 233 & 46.18 & 19.85 & 37.06 & 29.75 & 7.31 \\
\hline 9 & A9 & & & $180^{\circ} \mathrm{C}-4.5 \mathrm{~h}$ & 221 & 43.93 & 21.04 & 48.53 & 45.25 & 3.28 \\
\hline 10 & A10 & & & $180^{\circ} \mathrm{C}-5 \mathrm{~h}$ & 228 & 45.33 & 14.96 & 79.64 & 74.67 & 4.97 \\
\hline 11 & A11 & & & $180^{\circ} \mathrm{C}-5.5 \mathrm{~h}$ & 232 & 46.04 & 15.38 & 90.50 & 88.53 & 1.97 \\
\hline 12 & B1 & \multirow{11}{*}{$540^{\circ} \mathrm{C}-3 \mathrm{~h}$} & \multirow{11}{*}{$20 \mathrm{~h}$} & $180^{\circ} \mathrm{C}-0.5 \mathrm{~h}$ & 95 & 18.81 & 27.88 & 42.82 & 40.08 & 2.74 \\
\hline 13 & $\mathrm{~B} 2$ & & & $180^{\circ} \mathrm{C}-1 \mathrm{~h}$ & 128 & 25.40 & 15.85 & 91.83 & 87.51 & 4.32 \\
\hline 14 & B3 & & & $180^{\circ} \mathrm{C}-1.5 \mathrm{~h}$ & 175 & 34.81 & 12.00 & 144.68 & 142.63 & 2.05 \\
\hline 15 & B4 & & & $180^{\circ} \mathrm{C}-2 \mathrm{~h}$ & 184 & 36.49 & 11.54 & 129.41 & 125.20 & 4.21 \\
\hline 16 & B5 & & & $180^{\circ} \mathrm{C}-2.5 \mathrm{~h}$ & 208 & 41.54 & 15.08 & 86.07 & 83.71 & 2.36 \\
\hline 17 & B6 & & & $180^{\circ} \mathrm{C}-3 \mathrm{~h}$ & 210 & 41.68 & 11.96 & 112.25 & 106.46 & 5.79 \\
\hline 18 & B7 & & & $180^{\circ} \mathrm{C}-3.5 \mathrm{~h}$ & 217 & 42.95 & 12.50 & 113.00 & 108.32 & 4.68 \\
\hline 19 & B8 & & & $180^{\circ} \mathrm{C}-4 \mathrm{~h}$ & 225 & 44.63 & 16.04 & 102.47 & 104.34 & -1.87 \\
\hline 20 & B9 & & & $180^{\circ} \mathrm{C}-4.5 \mathrm{~h}$ & 223 & 44.07 & 13.54 & 99.02 & 94.08 & 4.94 \\
\hline 21 & B10 & & & $180^{\circ} \mathrm{C}-5 \mathrm{~h}$ & 216 & 42.95 & 13.00 & 109.81 & 104.21 & 5.6 \\
\hline 22 & B11 & & & $180^{\circ} \mathrm{C}-5.5 \mathrm{~h}$ & 224 & 44.49 & 16.00 & 95.41 & 94.99 & 0.42 \\
\hline 23 & $\mathrm{C} 1$ & \multirow{11}{*}{$540^{\circ} \mathrm{C}-6 \mathrm{~h}$} & \multirow{11}{*}{$20 \mathrm{~h}$} & $180^{\circ} \mathrm{C}-0.5 \mathrm{~h}$ & 82 & 16.28 & 20.12 & 104.76 & 107.27 & -2.51 \\
\hline 24 & $\mathrm{C} 2$ & & & $180^{\circ} \mathrm{C}-1 \mathrm{~h}$ & 150 & 29.75 & 16.88 & 74.19 & 70.04 & 4.15 \\
\hline 25 & $\mathrm{C} 3$ & & & $180^{\circ} \mathrm{C}-1.5 \mathrm{~h}$ & 178 & 35.23 & 14.54 & 92.45 & 88.61 & 3.84 \\
\hline 26 & $\mathrm{C} 4$ & & & $180{ }^{\circ} \mathrm{C}-2 \mathrm{~h}$ & 195 & 38.60 & 15.46 & 85.77 & 81.94 & 3.83 \\
\hline 27 & $\mathrm{C} 5$ & & & $180^{\circ} \mathrm{C}-2.5 \mathrm{~h}$ & 202 & 40.14 & 18.08 & 69.49 & 66.28 & 3.21 \\
\hline 28 & C6 & & & $180{ }^{\circ} \mathrm{C}-3 \mathrm{~h}$ & 213 & 42.39 & 20.50 & 55.43 & 50.81 & 4.62 \\
\hline 29 & $\mathrm{C} 7$ & & & $180^{\circ} \mathrm{C}-3.5 \mathrm{~h}$ & 209 & 41.44 & 16.04 & 74.13 & 70.01 & 4.12 \\
\hline 30 & $\mathrm{C} 8$ & & & $180^{\circ} \mathrm{C}-4 \mathrm{~h}$ & 223 & 44.15 & 14.38 & 85.10 & 78.98 & 6.12 \\
\hline 31 & $\mathrm{C} 9$ & & & $180^{\circ} \mathrm{C}-4.5 \mathrm{~h}$ & 224 & 44.34 & 19.31 & 59.63 & 55.02 & 4.61 \\
\hline 32 & $\mathrm{C} 10$ & & & $180^{\circ} \mathrm{C}-5 \mathrm{~h}$ & 220 & 43.51 & 16.92 & 70.10 & 65.12 & 4.98 \\
\hline 33 & $\mathrm{C} 11$ & & & $180^{\circ} \mathrm{C}-5.5 \mathrm{~h}$ & 220 & 43.79 & 22.19 & 46.89 & 42.38 & 4.51 \\
\hline 34 & $\mathrm{Z1}$ & NIL & NIL & NIL & 174 & 34.53 & 16.77 & 77.20 & 72.27 & 4.93 \\
\hline
\end{tabular}

The compression load was stopped well before the initial crack formation at $0.2 \%$ yield load. The artificial aging at $180{ }^{\circ} \mathrm{C}$ was divided into three zones on the basis of the duration such as zone 1: $(0.5 \mathrm{~h}$ to $1.5 \mathrm{~h})$, zone 2 : $(1.5 \mathrm{~h}$ to $4 \mathrm{~h})$ and zone 3 : ( $4 \mathrm{~h}$ to $5.5 \mathrm{~h})$ as significant changes were observed at these zones. Fig. 3 shows the plot between compression stress, barrel radius versus specimen no for three series of heat treated specimens. The positive number effect in strengthening the material on the artificial aging is evident. The natural aging of $20 \mathrm{~h}$ showed increase in compressive strength in zone 1 when compared to without natural aging. This is due to the formation of globular eutectic silica of a large volume. Aluminum alloys have high ductility after solution treatment, but, after aging, there is an increase in strength properties [16]. In zone 2, there was no significant difference in compressive strength for all the three heat treatments (A, B, C series) material and this is due to the dissolution of $\mathrm{Mg}$ and $\mathrm{Si}$ particles. As the artificial aging time increased the compressive strength also increased linearly. The peak compressive strength was obtained for A-series material at $4 \mathrm{hr}$ of artificial aging. In zone 3, there was no significant increase in compressive strength. Pezda [17] showed similar results that the largest increases in tensile strength (up to $426 \mathrm{MPa}$ ) and hardness obtained after solution treatment at $520-530{ }^{\circ} \mathrm{C}$ for $0.5-1.5 \mathrm{~h}$ and aging at $180{ }^{\circ} \mathrm{C}$ for $5-8 \mathrm{~h}$.

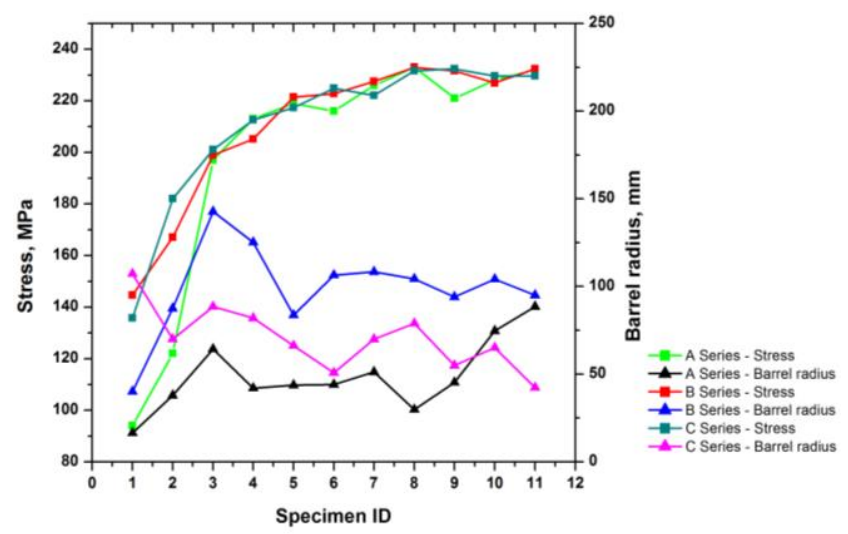

Fig. 3. Compressive stress vs. barrel radius plot

The histogram of compressive stress and barrel radius 
plot as shown in Fig. 4, revealed that the different density levels of stress and barrel radius data was formed at each heat treatment process. The data followed a normal distribution pattern and an exact bell-shaped curve was observed, because the heat treatment process influenced the compressive stress and barrel radius.

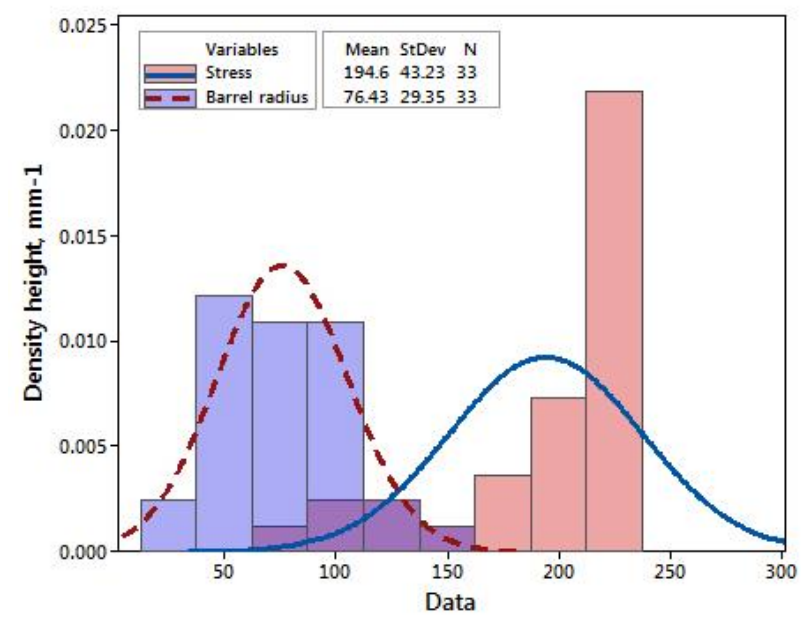

Fig. 4. Histogram of compressive stress and barrel radius with normal distribution fit

After compression, the final height, base diameter, equatorial diameter was measured using a digital Vernier caliper. The measured values were used for calculating the barrel radius using Eq. $1\left(R_{\mathrm{a}}\right)$ and Eq. $2\left(R_{\mathrm{b}}\right)$, upsetting ratio and deviation $\left(R_{\mathrm{a}}-R_{\mathrm{b}}\right)$ are given in Table. 1. According to the law of volume constancy, the height of the finished sample is reduced and the diameter is increased. The calculated barrel radius using Eq. $1\left(R_{\mathrm{a}}\right)$ and Eq. $2\left(R_{\mathrm{b}}\right)$ did not show much deviation, thus confirming assumption that the radius of curvature of barrel fits a circular arc. When the barrel radius is high, the material behaves ductile in nature and plastic deformation is high with reduction in height. From Fig. 3, for three series of heat treatments, specimens in zone 2 showed a distinct behaviour of materials. The compressive stress was similar for three series of heat treatment, but the ductility of the material showed a difference as observed in the barrel formation. The $20 \mathrm{~h}$ of natural aging prior to artificial aging had increased the dissolution of intermetallic precipitates $\left(\mathrm{Mg}_{2} \mathrm{Si}\right)$ and the increase in the duration of artificial aging increased the strength of the material. It was validated from the EDS analysis where a reduction of $\mathrm{Mg}$ content was revealed, caused by the dissolution of $\mathrm{Mg}_{2} \mathrm{Si}$ phase and is shown in Fig. 5.

In series A material, as noted dwindling strength delayed due to the reduction in the dissolution of $\mathrm{Mg}_{2} \mathrm{Si}$ precipitates/

\subsection{Effect of heat treatment on barrel radius}

Workability is the ease with which a material can be subjected to plastic deformation to achieve the desired shape without crack formation. The simple upset test serves as the effective technique for developing the workability limits for materials. From Fig. 6 it is evident that, when upset ratio is high, the barrel radius is low and vice-versa. It was stated in [18] that an increase in aging time is accompanied by a decrease in elongation.

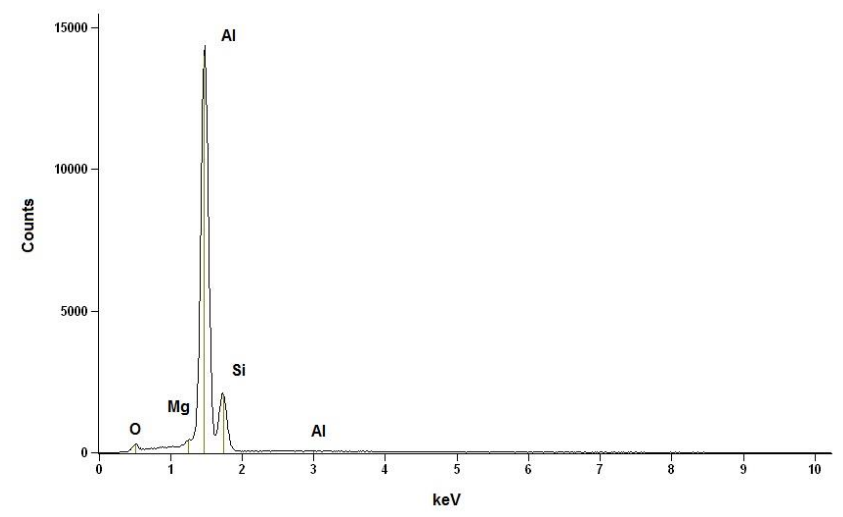

Fig. 5. EDS spectrum of B5 specimen solutionized at $540{ }^{\circ} \mathrm{C}$ for $3 \mathrm{~h}+$ natural aging for $20 \mathrm{~h}+$ artificial aging at $180^{\circ} \mathrm{C}$ for $1.5 \mathrm{~h}$

As the compression was done under friction, the material deformation was restricted to the interface of the die and material surface while the material undergoes plastic deformation at the equatorial region with a formation of bulge or barrel.

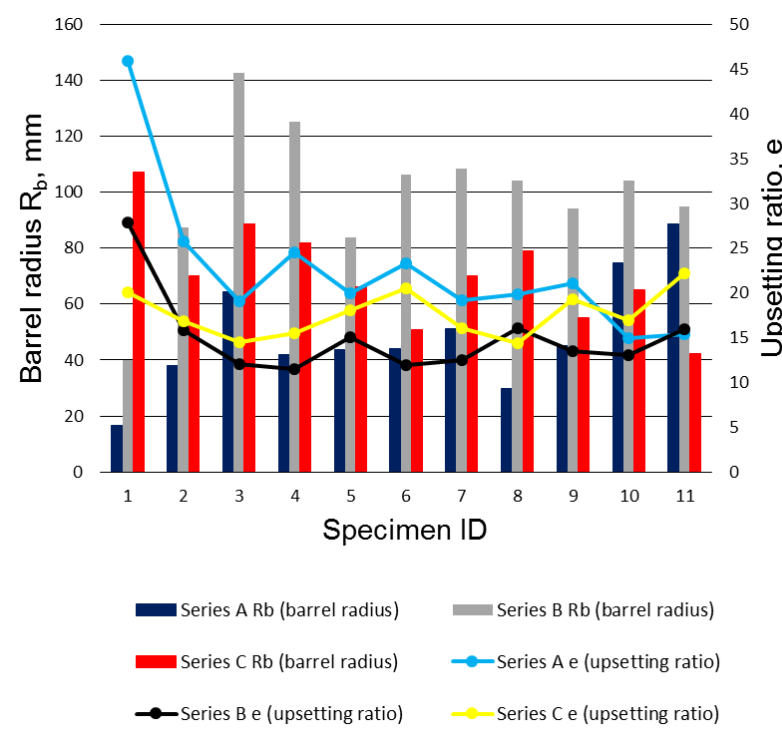

Fig. 6. Barrel radius vs. upsetting ratio plot

At zone 1: The series-A and series $-\mathrm{B}$ had an increasing trend in barrel radius while the series $-\mathrm{C}$ had an initial decrement and latter increased. At zone 2: In series $\mathrm{A}$, barrel radius was stable upto $3.5 \mathrm{~h}$ and a sudden decrease at $4 \mathrm{~h}$. Series $-\mathrm{B}$ and series $-\mathrm{C}$ showed a decrease in the barrel radius upto $2.5 \mathrm{~h}$ and $3 \mathrm{~h}$ respectively. This shows increase in solution treatment time reducing the artificial aging time in obtaining the peak properties. At zone 3: The series - A had an increasing trend in the barrel radius while, the series $-\mathrm{B}$ showed stable values and series $-\mathrm{C}$ showed a decreasing trend.

\section{CONCLUSIONS}

The modified heat treatment of A356 alloy was successfully completed. The effect of aging on compression led to the identification of the specific duration to obtain the desired material strength such as: 
1. Artificial aging shows a positive effect on the material strength.

2. The heat treatment with $20 \mathrm{~h}$ of natural aging showed improved strength.

3. The $1 \mathrm{~h}$ of solution treatment at $540{ }^{\circ} \mathrm{C}$ combined with $4 \mathrm{~h}$ of artificial aging at $180^{\circ} \mathrm{C}$ showed maximum compression strength.

4. Different barrel radii obtained based on modified heat treatment leads to the conclusion that the material deformability changes according to the changes in intermetallic precipitates and its microstructure.

5. The barrel radius is least at $4 \mathrm{~h}, 2.5 \mathrm{~h}$ and $3 \mathrm{~h}$ of artificial aging for material heat treated at series A, series B and Series C conditions respectively.

\section{REFERENCES}

1. ASM specialty handbook: Aluminium and Aluminium Alloys. ASM International, Materials park, Ohio, 1993. pp. $315-316$.

2. Menargues, S., Martin, E., Baile, M.T., Picas, J.A. New Short T6 Heat Treatments for Aluminium Silicon Alloys Obtained by Semisolid Forming Materials Science \& Engineering A 621 2015: pp. 236-242.

https://doi.org/10.1016/j.msea.2014.10.078

3. Yao, J.Y., Taylor, J.A. Characterisation of Intermetallic Particles Formed During Solution Treatment of an $\mathrm{Al}-7 \mathrm{Si}-$ $0.4 \mathrm{Mg}-0.12 \mathrm{Fe}$ Alloy Journal of Alloys and Compounds 519 2012: pp. 60-66. https://doi.org/10.1016/j.jallcom.2011.12.047

4. Rosso, M., Actis Grande, M. Optimization of Heat Treatment Cycle for Automotive Parts Produced by Rheocasting Process Solid State Phenomena 116-117 2006: pp. $505-508$. https://doi.org/10.4028/www.scientific.net/SSP.116-117.505

5. Dewhirst, B.A. Optimization of Heat Treatment of SemiSolid Processed A356 Aluminum Alloy. Master's thesis, Worcester Polytechnic Institute, 2005.

6. Shivkumar, S., Ricci, S., Steenhoff, B., Apeliam, D., Sigworth, G. An Experimental Study to Optimize the Heat Treatment of A356 Alloy AFS Trans 138 1989: pp. $791-810$.

7. Zhang, D.L., Zheng, L. The Quench Sensitivity of Cast Al7wt\%Si-0.4wt\%Mg Alloy Metallurgical and Materials Transactions 27 1996: pp. 3983-3991. https://doi.org/10.1007/BF02595647

8. Dumont, D., Deschamps, A., Brechet, Y. On the Relationship Between Microstructure, Strength and Toughness in AA7050 Aluminum Alloy Materials Science \& Engineering A $356(1-2)$ 2003: pp. 326-336. https://doi.org/10.1016/S0921-5093(03)00145-X
9. Tahir, A. An Experimental Study of Barreling and Fem Based Simulation in Cold Upsetting of Aluminum International Journal of Modern Manufacturing Technologies III (1) 2011: pp. 9-14.

10. Koboyashi, S. Deformation Characteristics and Ductile Fracture at 1040 Steel in Simple Upsetting of Solid Cylinders and Rings ASME Journal of Engineering for Industry 92 (2) 1970: pp. $391-398$. https://doi.org/10.1115/1.3427752

11. Gupta, R.K., $\quad$ Panda, R., Mukhopadhyay, A.K., Anil Kumar, V., Sankaravelayutham, P., Koshy, M.G. Study of Aluminum Alloy AA2219 After Heat Treatment Metal Science and Heat Treatment 57 (5-6) 2015: pp. $350-353$. https://doi.org/10.1007/s11041-015-9888-0

12. Abhijit, M. A Systematic Approach to Determine the Impact of Upsetting Ratio During Free Cold Forging Operation of Commercially Pure Aluminium in Dry Condition Procedia Materials Science 5 2014: pp. $1281-1290$. https://doi.org/10.1016/j.mspro.2014.07.440

13. Banerjee, J.K. Barreling of Solid Cylinders Under Axial Compression ASME Journal of Engineering Materials and Technology 107 (2) 1985: pp. 138-144. https://doi.org/10.1115/1.3225789

14. Cem, S.C. Effect of Aspect Ratio on Barreling Contour and Variation of Total Surface Area During Upsetting of Cylindrical Specimen Materials and Design 28 (6) 2007: pp. $1907-1913$. https://doi.org/10.1016/j.matdes.2006.03.027

15. Narayanasamy, R., Pandey, K.S. Phenomenon of Barreling in Aluminium Solid Cylinders During Cold UpsetForming Journal of Materials Processing Technology $70(1-3)$ 1997: pp. 17-21. https://doi.org/10.1016/S0924-0136(97)00035-6

16. Demiroren, H. Effect of Hardening Conditions on Aluminum Alloy Microstructure Metal Science and Heat Treatment 54 (5-6) 2012: pp. 294-297. https://doi.org/10.1007/s11041-012-9500-9

17. Pezda, J. Optimization of the T6 Heat Treatment to Improve the Mechanical Properties of Alloy AlSi12CuNiMg Metal science and heat treatment 57 (5-6) 2015: pp. 286-290. https://doi.org/10.1007/s11041-015-9876-4

18. Toozandehjani, M., Mustapha, F., Ariffin, M.K.A., Zahari, N.I., Matori, K.A., Ostovan, F., Fadaeifard, F. Effect of Artificial Aging on the Microstructure and Mechanical Properties of Aluminum Alloy AA6061-T6 Metal Science and Heat Treatment 58 (5-6) 2016: pp. $283-286$.

https://doi.org/10.1007/s11041-016-0004-x 